\title{
STRATEGI PENGEMBANGAN DAERAH GROWTH POLE MELALUI PEMANFAATAN POTENSI LOKAL
}

\author{
Rusdiarti \\ Universitas Negeri Semarang \\ Fafurida \\ Universitas Negeri Semarang \\ fafurida@mail.unnes.ac.id
}

\begin{abstract}
This research aims to determine the leading sectors that could be developed in each district in Cilacap Regency as a growth pole area. We use location quotient, shift share, and klassen typology as analysis methods. The research results show that not all of the district at Cilacap regency have a leading sector. Further, districts that have leading sectors are as follows. Wanareja only has a leading sector, i.e. agriculture. Secondly, Kawunganten has two leading sectors, agriculture and finance, rent, and company services. Thirdly, Agriculture becomes the only leading sector of Kampung Laut District. Fourthly, Mining and extraction are the leading sectors of Kesugihan District. Fifthly, Sampang District has buildings and finance sectors as the leading sectors. Sixthly, Kroya District leads in trade, hotel, and restaurant sectors. Seventhly, South Cilacap District leads in mining and extraction sectors. Eighthly, Central Cilacap District has manufacturing, electricity, gas and clean water, building and services as leading sectors. Lastly, North Cilacap District has electricity, gas and clean water, manufacturing, building and services as leading sectors.
\end{abstract}

Keywords: planning, development, local potential, growth pole.

\begin{abstract}
ABSTRAK
Tujuan dari penelitian ini adalah menentukan sektor unggulan yang dapat dikembangkan di tiap kecamatan di Kabupaten Cilacap sebagai salah satu daerah growth pole. Alat analisis yang digunakan dalam penelitian ini yaitu location quotient, shift share dan klassen typologi. Hasil penelitian menunjukkan tidak semua kecamatan di kabupaten Cilacap memiliki sektor unggulan. Beberapa daerah yang memiliki sektor unggulan diantaranya adalah Kecamatan Wanareja hanya memiliki satu sektor unggulan yaitu pertanian. Kedua adalah Kecamatan Kawunganten memiliki dua sektor unggulan yaitu sektor pertanian dan sektor keuangan, persewaan dan jasa perusahaan. Kecamatan Kampung Laut, dimana sektor pertanian pada kecamatan ini sangatlah unggul. Kecamatan kesugihan juga memiliki satu sektor unggulan yaitu sektor pertambangan dan penggalian. Kecamatan yang kelima yaitu Kecamatan Sampang, unggul dalam sektor bangunan dan sektor keuangan, persewaan dan jasa perusahaan. Keenam adalah Kecamatan Kroya unggul dalam sektor perdagangan, hotel dan restoran. Ketujuh yaitu Kecamatan Cilacap Selatan, sektor pertambangan dan penggalian di wilayah ini termasuk unggul. Cilacap tengah
\end{abstract}


memiliki banyak sektor unggulan, diantaranya adalah sektor Industri pengolahan, sektor listrik, gas dan air bersih, sektor bangunan serta sektor jasa-jasa. Dan Kecamatan Cilacap Utara, sektor yang tergolong unggul dalam kecamatan ini adalah sektor listrik, gas dan air bersih, sektor industri pengolahan, sektor bangunan dan sektor jasa-jasa.

Kata kunci: perencanaan, pengembangan,potensi lokal, growth pole.

\section{PENDAHULUAN}

Provinsi Jawa Tengah memiliki banyak wilayah kabupaten dan kota yang mengakibatkan terjadinya perbedaan. Telah terjadi ketimpangan ekonomi antar daerah dan disparitas yang tinggi di Propinsi Jawa Tengah. Hal tersebut ditunjukkan oleh hasil perhitungan Indeks Williamson untuk Propinsi Jawa Tengah, masih menunjukkan angka yang tinggi yaitu sebesar 0,727 (Fafurida 2010). Berdasar masalah tersebut maka diperlukan adanya solusi untuk memecahkan masalah yang ada. Salah satunya yaitu dengan cara menentukan daerah-daerah kutub pertumbuhan. Sesuai dengan teori Growth Pole yang menyatakan bahwa untuk tumbuh dengan cepat, suatu daerah perlu memilih satu atau lebih pusat-pusat pertumbuhan regional yang mempunyai potensi paling kuat. Dari hasil penelitian sebelumnya diketahui dalam perencanaan ekonomi dan wilayah Propinsi Jawa Tengah ditentukan growth pole untuk wilayah bagian pertama yaitu Kabupaten Cilacap, growth pole untuk wilayah bagian kedua yaitu Kota Semarang dan growth pole untuk wilayah bagian ketiga yaitu Kabupaten Kudus. Setelah diketahui beberapa daerah yang menjadi growth pole maka perlu dibuat analisis lebih lanjut untuk menyusun perencanaan yang lebih rinci di daerah-daerah growth pole. Agar perencanaan yang disusun dapat sesuai dengan kondisi daerah masing-masing dan dapat diimplementasikan di daerah tersebut.

Tujuan yang diharapkan untuk dicapai dari penelitian ini adalah menentukan sektor unggulan yang dapat dikembangkan di tiap kecamatan di Kabupaten Cilacap sebagai salah satu daerah growth pole. Perlu dorongan pertumbuhan sektor basis untuk mendorong pertumbuhan suatu wilayah. Hal ini karena pertumbuhan tersebut akan mendorong pertumbuhan sektor lainnya, yaitu sektor non basis. Sektor basis merupakan sektor yang menjual produknya ke luar wilayah atau kegiatan yang mendatangkan uang dari luar wilayah (Irmawati 2015). Dengan identifikasi sektor unggulan ini diharapkan akan terjadi peningkatan dan pengembangan ekonomi daerah growth pole melalui pemanfaatan potensi lokal, menurut Blakely (1994) mengemukakan bahwa basis dari pembangunan ekonomi regional adalah pemanfaatan potensi sumber daya manusia dan sumber daya alam untuk menciptakan lapangan kerja baru serta mendorong tumbuhnya basis perekonomian baru. Setelah pengembangan daerah growth pole terjadi diharapkan akan terjadi perembetan atau imbas positif terhadap daerah-daerah di sekitar growth pole. Sehingga dapat menciptakan pertumbuhan tertinggi, pada saat yang sama tujuan 
utama dari upaya pembangunan ekonomi juga harus menghapus atau mengurangi tingkat kemiskinan, ketimpangan pendapatan, dan tingkat pengangguran (Todaro 2003). Menurut Djojohadikusumo (1994), pertumbuhan ekonomi berpokok pada proses peningkatan produksi barang dan jasa dalam kegiatan ekonomi masyarakat. Sedangkan menurut Arsyad (1999) pembangunan ekonomi daerah adalah proses dimana pemerintah daerah dan masyarakat mengelola sumberdaya yang ada melalui suatu pola kemitraan antara pemerintah dengan sektor swasta untuk menciptakan lapangan kerja baru dan merangsang perkembangan kegiatan ekonomi (pertumbuhan ekonomi) dalam wilayah tersebut. Sesungguhnya sebuah pembangunan di suatu daerah pada dasarnya adalah upaya untuk meningkatkan kapasitas pemerintah, sektor swasta, masyarakat, dan pemangku kepentingan terkait dalam pengelolaan sumber daya ekonomi di efisien dan efektif cara untuk kemajuan daerah dan kesejahteraan sosial (Sarwono 2016).

\section{Teori Growth Pole (Kutub Pertumbuhan) dan Pusat Pertumbuhan}

Perroux (1970) mendefinisikan sebuah kutub pertumbuhan sebagai suatu kumpulan industri yang akan mampu menggerakkan pertumbuhan ekonomi suatu negara karena industri-industri tersebut mempunyai kaitan kemuka (forward linkage) dan kaitan ke belakang (backward linkage) yang kuat dengan industri unggul. Dia mengatakan bahwa kumpulan industri cenderung untuk memilih lokasi yang memusat pada kota-kota besar dan didukung oleh sebuah daerah belakang (hinterland) yang kuat. Sebuah wilayah potensial merupakan wilayah yang kurang berkembang atau tidak berkembang sama sekali tetapi memiliki faktor-faktor yang dapat menyebabkan untuk mengembangkan cepat jika ada perkembangan (Sukirno 1985).

Perroux (1970) mengatakan pertumbuhan tidak muncul di berbagai daerah pada waktu yang sama. Pertumbuhan hanya terjadi di beberapa tempat yang disebut pusat pertumbuhan. Inti dari teori Pusat Pertumbuhan adalah sebagai berikut, pertama dalam proses pembangunan akan timbul industri unggulan yang merupakan industri penggerak utama dalam pembangunan ekonomi daerah. Karena keterkaitan antar industri sangat erat, maka perkembangan industri unggulan akan mempengaruhi perkembangan industri lain yang berhubungan erat dengan industri tersebut. Kedua, pemusatan industri pada suatu daerah akan mempercepat pertumbuhan perekonomian, karena pemusatan industri akan menciptakan pola konsumsi yang berbeda antar daerah sehingga perkembangan industri di daerah tersebut akan mempengaruhi perkembangan daerah-daerah lainnya. Ketiga, perekonomian merupakan gabungan dari sistem industri yang relatif aktif (industri unggulan) dengan industri-industri yang relatif pasif yaitu industri yang tergantung dari industri unggulan atau pusat pertumbuhan. Daerah yang relatif maju atau aktif akan mempengaruhi daerah-daerah yang relatif pasif.

Adanya growth pole, akan menimbulkan trickling down dan polarization effects suatu pertumbuhan ekonomi. Trickling down dan polarization effects suatu 
pertumbuhan ekonomi ditemukan oleh Hirschman (1958). Ia berpendapat bahwa karena potensi sumber daya yang tidak seragam dan tidak merata antara region satu dengan region lainnya maka region-region dalam sebuah negara akan tumbuh tidak sama dan tidak seragam. Untuk dapat tumbuh dengan cepat, suatu negara perlu memilih satu atau lebih pusat-pusat pertumbuhan regional yang mempunyai potensi paling kuat.

Apabila region-region kuat ini telah tumbuh maka akan terjadi perembetan pertumbuhan bagi region-region yang lemah. Perembetan pertumbuhan ini bisa berdampak positif (trickling down effects), yaitu adanya pertumbuhan region yang kuat dan menyerap potensi tenaga kerja di region yang lemah yang masih menganggur atau mungkin region yang lemah menghasilkan produk yang sifatnya komplementer dengan produk region yang lebih kuat. Sedangkan dampak negatif (polarization effect) terjadi kalau kegiatan produksi di region yang kuat bersifat kompetitif dengan produk region yang lemah, yang sebenarnya membutuhkan pembinaan.

\section{Teori Basis Ekonomi}

Teori ini menyatakan bahwa pertumbuhan suatu wilayah sangat tergantung kepada kemampuan wilayah itu untuk mengekspor barang atau jasa. Menurut North (1975), pertumbuhan wilayah dalam jangka panjang tergantung industri ekspornya. Kekuatan utama pertumbuhan wilayah adalah permintaan dari luar akan barang dan jasa yang dihasilkan dan diekspor. Permintaan dari luar wilayah mempengaruhi penggunaan modal, tenaga kerja, dan teknologi untuk menghasilkan ekspor sehingga terbentuk keterkaitan ekonomi baik kebelakang maupun kedepan. Menurut Hoover (1984), pertumbuhan beberapa sektor basis akan menentukan pembangunan daerah secara keseluruhan, sementara sektor non basis hanya merupakan konsekuensikonsekuensi dari pembangunan daerah. Barang dan jasa dari sektor basis yang diekspor akan menghasilkan pendapatan bagi daerah serta meningkatkan konsumsi dan investasi. Peningkatan pendapatan tidak hanya menyebabkan kenaikan permintaan terhadap sektor basis, tetapi juga akan menaikan permintaan terhadap sektor non basis berarti juga mendorong kenaikan investasi sektor non basis. Penggunaan teori ini dalam suatu studi dimaksudkan untuk mengidentifikasi sektorsektor pembangunan yang termasuk sektor basis maupun non basis pada suatu daerah.

\section{METODA PENELITIAN}

Penelitian ini merupakan penelitian kuantitatif dengan analisis data yang dilakukan menggunakan perhitungan-perhitungan angka. Adapun jenis data yang digunakan dalam penelitian ini adalah data sekunder. Data sekunder diperoleh dari berbagai sumber yaitu BPS Kabupaten Cilacap, BAPPEDA Kabupaten Cilacap serta instansi yang terkait lainnya. Data tersebut meliputi data PDRB per sektor, dari tahun 
2007 sampai tahun 2011. Sedangkan alat analisis yang digunakan dalam penelitian ini yaitu location quotient, shift share dan klassen typologi.

Untuk mengidentifikasi sektor unggulan yang terdapat di Kabupaten Cilacap, dalam penelitian ini digunakan dua pendekatan yaitu comparative advantage dan competitive advantage. Analisis yang digunakan adalah location quotient, shift share dan klassen tipology. Analisis location quotient dalam penelitian ini digunakan untuk mengidentifikasi sektor yang memiliki comparative advantage, sedangkan analisis shift share digunakan untuk mengidentifikasi sektor yang memiliki competitive advantage. Untuk megidentifikasi sektor unggulannya menggunakan analisis Klassen Tipology. Suatu sektor dapat dikatakan unggul apabila sektor tersebut memiliki kedua keunggulan tersebut, baik comparative advantage maupun competitive advantage. Artinya, suatu sektor dalam perekonomian benar-benar dikatakan unggul apabila sektor tersebut dapat menghasilkan output yang banyak (dapat melakukan ekspor) dan mampu bersaing dengan sektor yang sama dari daerah lain.

\section{ANALISIS DAN PEMBAHASAN}

Kabupaten Cilacap memiliki 24 kecamatan yang terdapat didalamnya. Perbedaan kondisi geografis dan sumber daya yang dimiliki menyebabkan potensi tiap kecamatan yang ada di Kabupaten Cilacap juga berbeda-beda. Dalam perencanaan pengembangan ekonomi dan wilayah dalam penelitian ini, identifikasi sektor unggulan dan perencanaan akan dilakukan melalui identifikasi di masingmasing kecamatan di Kabupaten Cilacap.

\section{Sektor yang Memiliki Comparative Advantage}

Suatu sektor dikatakan memiliki comparative advantage apabila output dari sektor tersebut berlimpah, output tersebut dapat memenuhi permintaan masyarakat dalam daerah dan dapat melakukan ekspor ke luar daerah. Indikator comparative advantage tersebut ditunjukkan oleh koefisien LQ (Location Quotient) yang bernilai lebih besar dari satu (Tabel 1, Lampiran).

Sektor yang memiliki comparative advantage di masing-masing kecamatan berbeda-beda. Namun secara umum, sektor yang memiliki comparative advantage yang banyak ditemukan di tiap kecamatan adalah sektor pertanian, sektor pertambangan dan penggalian, sektor bangunan dan sektor keuangan,persewaan dan jasa perusahaan.

Terdapat enam kecamatan yang memiliki comparative advantage di sektor pertanian yaitu Kecamatan Dayeuhluhur, Wanareja, Cipari, Bantarsari, Kawunganten dan Kampung Laut. Pada keenam kecamatan tersebut produksi hasil pertanian sangatlah melimpah dikarenakan luasnya penggunaan lahan yang digunakan untuk areal tanam komoditas pertanian. Selain itu ada pula daerah yang terletak di pesisir 
pantai yang menyebabkan produksi komoditas perikanan berlimpah. Sehingga output total pada sektor pertanian sangatlah tinggi.

Sejumlah kecamatan yang memiliki comparative advantage pada sektor pertambangan dan penggalian adalah Kecamatan Karang Pucung, Kadungreja, Patimuan, Gandrungmangu, Kesugihan dan Cilacap Selatan. Produktivitas barang tambang dan galian di keenam kecamatan tersebut tergolong tinggi jika dibandingkan dengan kecamatan yang lain. Posisi geografis wilayah yang berdekatan dengan pantai menyebabkan hasil tambang dan galian seperti pasir, dan lain-lain mempunyai nilai yang tinggi.

Sektor bangunan juga memiliki comparative advantage di banyak kecamatan di Kabupaten Cilacap. Terdapat lima kecamatan yang memiliki output yang tinggi pada sektor bangunan, diantaranya adalah Kecamatan Maos, Sampang, Binangun, Cilacap Tengah dan Cilacap Utara. Banyaknya alih fungsi lahan dari penggunaannya sebagai areal tanam pertanian menjadi perumahan dan pertokoan banyak dijumpai pada kelima kecamatan tersebut. Sehingga wajar jika sektor bangunan sangat berkembang di kelima kecamatan tersebut.

Sektor terakhir yang banyak memiliki output di Kabupaten Cilacap adalah sektor keuangan,persewaan dan jasa perusahaan. Kecamatan yang memiliki comparative advantage di sektor ini adalah Kecamatan Kedungreja, Patimuan, Gandrungmangu, Kawunganten dan Kecamatan Sampang. Di kelima kecamatan tersebut output sektor keuangan, persewaan dan jasa perusahaan memiliki nilai yang tinggi dibandingkan dengan kecamatan-kecamatan yang lain.

\section{Sektor yang Memiliki Competititive Advantage}

Syarat kedua untuk mengidentifikasi sektor unggulan adalah sektor tersebut harus memiliki competitive advantage. Suatu sektor dikatakan memiliki competitive advantage apabila output dari sektor tersebut mampu bersaing dengan sektor yang sama di daerah lain. Dalam penelitian ini indikator competitive advantage tersebut dilihat dari komponen Cij yang bernilai positif dari analisis Shift Share.

Dari tabel 2 (Lampiran), dapat dilihat hasil perhitungan dari analisis Shift Share yang telah dilakukan. Dari hasil analisis tersebut terlihat hampir semua sektor memiliki competitive advantage di banyak kecamatan. Dari sembilan sektor yang ada, sektor industri pangolahan menjadi sektor yang memiliki competitive advantage terbanyak di delapan belas kecamatan. Hampir di semua kecamatan memiliki competitive advantage di sektor ini kecuali Kecamatan Majenang, Kedungreja, Kesugihan, Binangun, Nusawungu dan Cilacap Selatan. Output dari sektor industri di delapan belas kecamatan tersebut sangatlah baik sehingga mampu berkompetisi dengan sektor yang sama di daerah lain.

Sektor kedua yang banyak memiliki competitive advantage di berbagai kecamatan adalah sektor listrik, gas dan air bersih. Daerah yang memiliki competitive advantage pada sektor listrik, gas dan air bersih terdapat di enam belas kecamatan yaitu Kecamatan Wanareja, Cimanggu, Karang Pucung, Sidareja, Bantarsari, Kawunganten, Kampung Laut, Jaruklegi, Adipala, Maos, Sampang, Kroya, 
Binangun, Nusawungu, Cilacap Tengah dan Cilacap Utara. Output dari sektor listrik, gas dan air bersih di keenam belas kecamatan tersebut sangatlah tinggi, sehingga wajar jika sektor ini mampu memiliki competitive advantage di keenam belas kecamatan tersebut.

Sektor ketiga yang banyak memiliki competitive advantage adalah sektor bangunan. Terdapat lima belas kecamatan yang memiliki competitive advantage di sektor ini. Banyak berkembangannya perumahan-perumahan rakyat dengan harga murah menyebabkan banyaknya alih fungsi lahan sehingga sektor bangunan saat ini sangatlah berkembang terutama di lima belas kecamatan tersebut.

\section{Sektor Unggulan}

Suatu sektor dapat dikatakan unggul apabila memiliki dua keunggulan yakni comparative advantage dan competitive advantage. Suatu sektor dikatakan potensial jika sektor tersebut memiliki satu keunggulan di antara dua keunggulan yang ada yakni comparative advantage atau competitive advantage saja. Sedangkan suatu sektor dikategorikan dalam sektor yang terbelakang apabila sektor tersebut tidak memiliki keunggulan baik comparative advantage maupun competitive advantage. Berikut ini adalah hasil Klassen Tipology tiap sektor di tiap kecamatan yang ada di Kabupaten Cilacap.

Dari hasil analisis klassen tipology tabel 3 (Lampiran) terlihat bahwa menunjukkan tidak semua kecamatan yang ada di Kabupaten Cilacap memiliki sektor unggulan. Hanya beberapa kecamatan saja yang memiliki sektor unggulan, di antaranya adalah Kecamatan Wanareja yang hanya memiliki satu sektor unggulan yaitu pertanian. Kedua adalah Kecamatan Kawunganten. Kecamatan ini memiliki dua sektor unggulan yaitu sektor pertanian dan sektor keuangan, persewaan dan jasa perusahaan. Berikutnya adalah Kecamatan Kampung Laut, sektor pertanian pada kecamatan ini sangatlah unggul. Kecamatan kesugihan juga memiliki satu sektor unggulan yaitu sektor pertambangan dan penggalian. Kecamatan yang kelima yaitu Kecamatan Sampang yang memiliki dua sektor unggulan di antaranya adalah sektor bangunan dan sektor keuangan, persewaan dan jasa perusahaan. Keenam adalah Kecamatan Kroya, sektor perdagangan, hotel dan restoran di kecamatan ini dapat dikategorikan dalam sektor unggulan.yang ke tujuh yaitu Kecamatan Cilacap Selatan. Sektor pertambangan dan penggalian di wilayah ini termasuk unggul dikarenakan posisi wilayahnya yang berada di pesisir pantai menyebabkan banyaknya potensi bahan tambang khususnya pasir dapat ditemukan di wilayah ini. Cilacap tengah merupakan kecamatan yang memiliki banyak sektor unggulan, diantaranya adalah sektor Industri pengolahan, sektor listrik, gas dan air bersih, sektor bangunan serta sektor jasa-jasa. Kecamatan terkhir yang memiliki banyak sektor unggulan adalah Kecamatan Cilacap Utara, sektor yang tergolong unggul dalam kecamatan ini adalah sektor listrik, gas dan air bersih, sektor industri pengolahan, sektor bangunan dan sektor jasa-jasa.

Sektor unggulan yang dimiliki oleh beberapa kecamatan merupakan suatu kekuatan yang dapat digunakan sebagai salah satu instrumen untuk pengembangan 
ekonomi dan wilayah. Sedangkan sektor potensial, dapat dikembangkan baik output secara kuantitas maupun kualitas agar dapat berkembang menjadi sektor unggulan. Sedangkan untuk sektor terbelakang dapat diusahakan pengembangannya agar mampu menjadi sektor potensial atau bahkan sektor unggulan

\section{SIMPULAN, KETERBATASAN DAN SARAN}

\section{Kesimpulan}

Tidak semua kecamatan di kabupaten Cilacap memiliki sektor unggulan. Beberapa daerah yang memiliki sektor unggulan di antaranya adalah Kecamatan Wanareja hanya memiliki satu sektor unggulan yaitu pertanian. Kedua adalah Kecamatan Kawunganten memiliki dua sektor unggulan yaitu sektor pertanian dan sektor keuangan, persewaan dan jasa perusahaan. Kecamatan Kampung Laut untuk sektor pertanian pada kecamatan ini sangat unggul. Kecamatan Kesugihan juga memiliki satu sektor unggulan yaitu sektor pertambangan dan penggalian. Kecamatan yang kelima yaitu Kecamatan Sampang, kecamatan ini memiliki dua sektor unggulan di antaranya adalah sektor bangunan dan sektor keuangan, persewaan dan jasa perusahaan. Keenam adalah Kecamatan Kroya, sektor perdagangan, hotel dan restoran di kecamatan ini dapat dikategorikan dalam sektor unggulan. Yang ke tujuh yaitu Kecamatan Cilacap Selatan, sektor pertambangan dan penggalian di wilayah ini termasuk unggul. Cilacap Tengah merupakan kecamatan yang memiliki banyak sektor unggulan, di antaranya adalah sektor Industri pengolahan, sektor listrik, gas dan air bersih, sektor bangunan serta sektor jasa-jasa. Kecamatan terkhir yang memiliki banyak sektor unggulan adalah Kecamatan Cilacap Utara, sektor yang tergolong unggul dalam kecamatan ini adalah sektor listrik, gas dan air bersih, sektor industri pengolahan, sektor bangunan dan sektor jasa-jasa.

\section{Saran}

1. Adanya sektor unggulan di tiap wilayah dapat digunakan sebagai salah satu instrumen pengembangan ekonomi daerah melalui penyusunan programprogram berbasis sektor unggulan.

2. Perlunya usaha pengembangan sektor potensial agar dapat menjadi sektor unggulan di semua kecamatan di Kabupaten Cilacap.

3. Perlunya usaha peningkatan produktifitas dan kualitas sektor terbelakang di semua kecamatan di Kabupaten Cilacap.

\section{DAFTAR PUSTAKA}

(BPS), Badan Pusat Statistik. n.d. "Jawa Tengah Dalam Angka 2008-2012.” BPS Propinsi Jawa Tengah. Semarang.

Arsyad, Lincolin. 1999. Pengantar perencanaan pembangunan ekonomi daerah, edisi pertama. Yogyakarta: BPFE. 
Blakely, Edward James. 1994. Planning local economic development theory and practice, 2nd ed. Australia: Thousand Oaks : Sage Publications.

Djojohadikusumo, Sumitro. 1994. Perkembangan Pemikiran Ekonomi: Dasar Teori Ekonomi, Pertumbuhan dan Ekonomi Pembangunan. Penerbit PT. Pustaka LP3ES.

Fafurida. 2010. "Kajian Penelitian Bidang Ilmu Ekonomi dan Studi Pembangunan, Manajemen dan Akuntansi dalam Rangka Memperkokoh Perekonomian Nasional." Proceeding. FE Universitas Sebelas Maret.

Hirschman, Albert O. 1958. The strategy of economic development in developing countries. Yale University Press. New Haven, Connecticut, USA.

Hoover, Edgar Malone. 1984. An Introduction to regional economics, 2nd ed. Knopf, new york: Alfred A. Knopf, Inc.

Irmawati, Setyani. 2015. "Analisis Industri Unggulan di Provinsi Jawa Tengah.” JEJAK 8 (2): 224-37.

Perroux, F. 1970. "Economic space: theory and applications." Quarterly Journal of Economics 64: 89-104.

Sarwono. 2016. "Analysis of economic growth factors in West Pantura areas of Central Java." JEJAK 9 (2): 145-58.

Sukirno, Sadono. 1985. Ekonomi Pembangunan - Proses, Masalah dan Dasar Kebijakan. Jakarta: LP3ES-UI dengan Bina Grafika.

Todaro, Michael P. 2003. Economic development eight edition. United Kingdom: Pearson Education Limited. 


\section{LAMPIRAN}

Tabel 1

Matriks Rata-rata Hasil Perhitungan Koefisien Location Quotient Tiap Kecamatan di Kabupaten Cilacap Tahun 2007 - 2011

\begin{tabular}{|c|c|c|c|c|c|c|c|c|c|}
\hline \multirow{2}{*}{ Kecamatan } & \multicolumn{9}{|c|}{ Sektor } \\
\hline & 1 & 2 & 3 & 4 & 5 & 6 & 7 & 8 & 9 \\
\hline Dayeuhluhur & 1,76 & 0,04 & 0,03 & 0,05 & 0,35 & 0,16 & 0,19 & 0,3 & 0,34 \\
\hline Wanareja & 1,06 & 0,07 & 0,26 & 0,1 & 0,6 & 0,76 & 0,34 & 0,51 & 0,53 \\
\hline Majenang & 0,54 & 0,6 & 0,77 & 0,46 & 0,16 & 1,03 & 0,61 & 0,66 & 0,43 \\
\hline Cimanggu & 0,9 & 0 & 0,62 & 0,02 & 0,58 & 0,76 & 0,43 & 0,51 & 0,28 \\
\hline Karang Pucung & 0,7 & 1,97 & 0,25 & 0,03 & 0,05 & 0,49 & 0,18 & 0,91 & 2,29 \\
\hline Cipari & 1,45 & 0,04 & 0,22 & 0,09 & 0,06 & 0,4 & 0,26 & 0,59 & 0,31 \\
\hline Sidareja & 0,77 & 0 & 0,39 & 0,14 & 0,12 & 1,09 & 1,03 & 0,43 & 0,41 \\
\hline Kedungreja & 0,52 & 2,63 & 0,59 & 0,11 & 0,9 & 0,48 & 0,62 & 1,55 & 0,68 \\
\hline Patimuan & 0,9 & 1,19 & 0,21 & 0,14 & 0,89 & 0,43 & 0,82 & 1,16 & 0,88 \\
\hline Gandrungmangu & 0,82 & 1,39 & 0,14 & 0,07 & 0,18 & 0,66 & 0,5 & 1,33 & 1,21 \\
\hline Bantarsari & 1,25 & 0 & 0,06 & 0,02 & 0,07 & 0,67 & 0,37 & 0,77 & 0,68 \\
\hline Kawunganten & 1,37 & 0,01 & 0,05 & 0,02 & 0,04 & 0,42 & 0,37 & 1,09 & 0,7 \\
\hline Kampung Laut & 1,61 & 0,01 & 0,01 & 0,02 & 0,04 & 0,51 & 0,1 & 0,03 & 0,4 \\
\hline Jeruklegi & 0,93 & 2,4 & 0,46 & 0,03 & 0,04 & 0,66 & 0,38 & 0,33 & 0,38 \\
\hline Kesugihan & 0,37 & 1,27 & 0,76 & 0,08 & 0,48 & 1,1 & 0,76 & 0,79 & 0,39 \\
\hline Adipala & 0,85 & 0,6 & 0,55 & 0,04 & 0,92 & 0,38 & 1,42 & 0,66 & 0,45 \\
\hline Maos & 0,34 & 0,32 & 0,28 & 0,15 & 5,15 & 0,6 & 0,62 & 0,46 & 0,82 \\
\hline Sampang & 0,48 & 0,24 & 0,42 & 0,11 & 1,92 & 0,67 & 1,79 & 1,29 & 0,33 \\
\hline Kroya & 0,45 & 0 & 0,39 & 0,17 & 0,07 & 1,44 & 0,93 & 0,55 & 0,84 \\
\hline Binangun & 0,96 & 0 & 0,56 & 0,06 & 1,1 & 0,49 & 0,13 & 0,64 & 0,75 \\
\hline Nusawungu & 0,87 & 0,93 & 0,53 & 0,06 & 0,46 & 0,46 & 0,74 & 0,69 & 0,83 \\
\hline Cilacap Selatan & 0,2 & 1,84 & 1,64 & 4,07 & 0,37 & 0,41 & 0,46 & 0,59 & 0,51 \\
\hline Cilacap Tengah & 0,03 & 0,22 & 1,18 & 1,37 & 1,05 & 0,6 & 1,65 & 0,82 & 1,37 \\
\hline Cilacap Utara & 0,04 & 0,24 & 1,73 & 1,96 & 1,04 & 0,49 & 0,73 & 0,64 & 1,01 \\
\hline
\end{tabular}

Sumber : Data BPS diolah

Keterangan tabel :

1 : Sektor pertanian

2 : Sektor pertambangan dan penggalian

3 : Sektor industri pengolahan

4 : Sektor listrik, gas dan air bersih

5 : Sektor bangunan

6 : Sektor perdagangan, hotel dan restoran

7 : Sektor pengangkutan dan komunikasi

8 : Sektor keuangan, persewaan dan jasa perusahaan

9 : Sektor jasa-jasa 


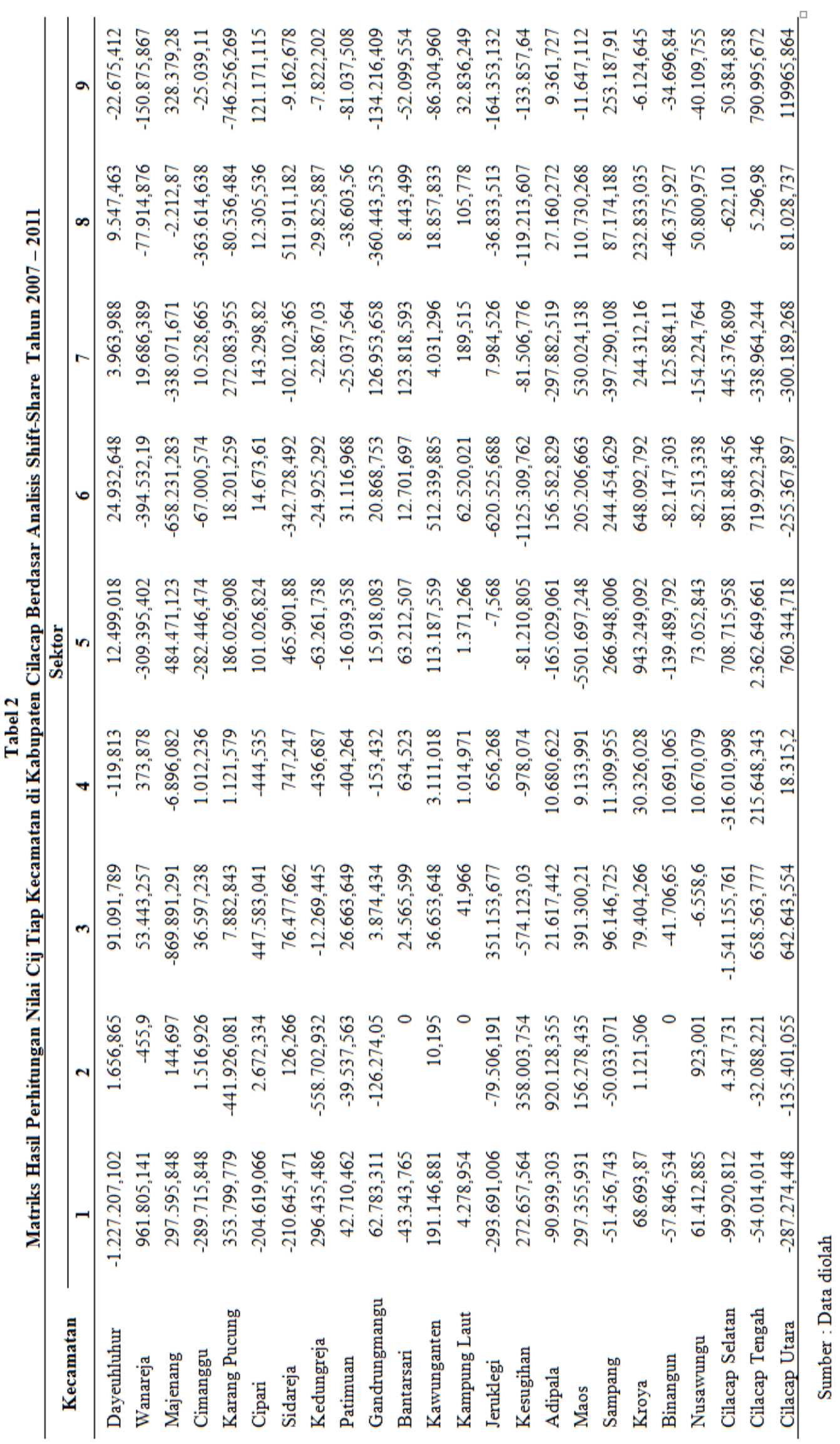


Keterangan tabel :

1: Sektor pertanian

2: Sektor pertambangan dan penggalian

3: Sektor industri pengolahan

4: Sektor listrik, gas dan air bersih

5: Sektor bangunan

6: Sektor perdagangan, hotel dan restoran

7: Sektor pengangkutan dan komunikasi

8: Sektor keuangan, persewaan dan jasa perusahaan

9: Sektor jasa-jasa

Tabel 3

Hasil Analisis Klassen Tipology Sektor Perekonomian Tiap Kecamatan di Kabupaten Cilacap

\begin{tabular}{|c|c|c|c|}
\hline \multirow{2}{*}{ Kecamatan } & \multicolumn{3}{|c|}{ Sektor } \\
\hline & Unggulan & Potensial & Terbelakang \\
\hline DAYEUHLUHUR & & $\begin{array}{l}\text { - Pertambangan dan } \\
\text { Penggalian } \\
\text { - Industri pengolahan } \\
\text { - } \text { Bangunan } \\
\text { - Perdagangan, Hotel dan } \\
\text { Restoran. } \\
\text { - Pengangkutan dan } \\
\text { Komunikasi. } \\
\text { - Keuangan, Persewaan, dan } \\
\text { Jasa Perusahaan. } \\
\text { - Pertanian. }\end{array}$ & $\begin{array}{l}\text { - Listrik, Gas dan Air } \\
\text { Bersih. } \\
\text { - Jasa-jasa. }\end{array}$ \\
\hline WANAREJA & - Pertanian & $\begin{array}{l}\text { - Pertambangan dan } \\
\text { Penggalian } \\
\text { - } \text { Industri pengolahan } \\
\text { - Listrik.gas dan air bersih } \\
\text { - Pengangkutan dan } \\
\text { komunikasi }\end{array}$ & $\begin{array}{ll}\text { - } & \text { Pertambangan dan } \\
& \text { Penggalian. } \\
\text { - } & \text { Bangunan } \\
\text { - } & \text { Perdagangan Hotel, dan } \\
& \text { Restoran } \\
\text { - } & \text { Keuangan, Persewaan \& } \\
& \text { jasa perushaan } \\
\text { - } & \text { Jasa-jasa }\end{array}$ \\
\hline MAJENANG & & $\begin{array}{l}\text { - Pertanian } \\
\text { - Pertambangan dan } \\
\text { Penggalian. } \\
\text { - Bangunan } \\
\text { - Jasa-jasa } \\
\text { - Perdagangan, Hotel dan } \\
\quad \text { Restoran }\end{array}$ & $\begin{array}{l}\text { - } \text { Industri pengolahan } \\
\text { - } \text { Listrik, Gas dan Air } \\
\text { Bersih } \\
\text { - } \text { Pengangkutan dan } \\
\text { Komunikasi } \\
\text { - Keuangan, Persewaan \& } \\
\text { jasa perushaan. }\end{array}$ \\
\hline CIMANGGU & & $\begin{array}{l}\text { - } \text { Pertambangan \& } \\
\text { Penggalian. } \\
\text { - } \text { Industri pengolahan } \\
\text { - Listrik, Gas \& Air Bersih } \\
\text { - Pengangkutan \& Komunikasi }\end{array}$ & $\begin{array}{l}\text { - Pertanian } \\
\text { - } \text { Bangunan } \\
\text { - Perdagangan Hotel dan } \\
\text { Restoran } \\
\text { - Keuangan, Persewaan } \\
\text { dan Jasa Perusahaan } \\
\text { - Jasa-jasa. }\end{array}$ \\
\hline KARANG PUCUNG & & $\begin{array}{l}\text { - Pertanian } \\
\text { - Industri pengolahan } \\
\text { - Listrik gas dan air bersih } \\
\text { - Bangunan } \\
\text { - Perdangan hotel dan restoran } \\
\text { - Pengangkutan dan }\end{array}$ & $\begin{array}{l}\text { Keuangan persewaaan } \\
\text { dan jasa perusahaan. }\end{array}$ \\
\hline
\end{tabular}




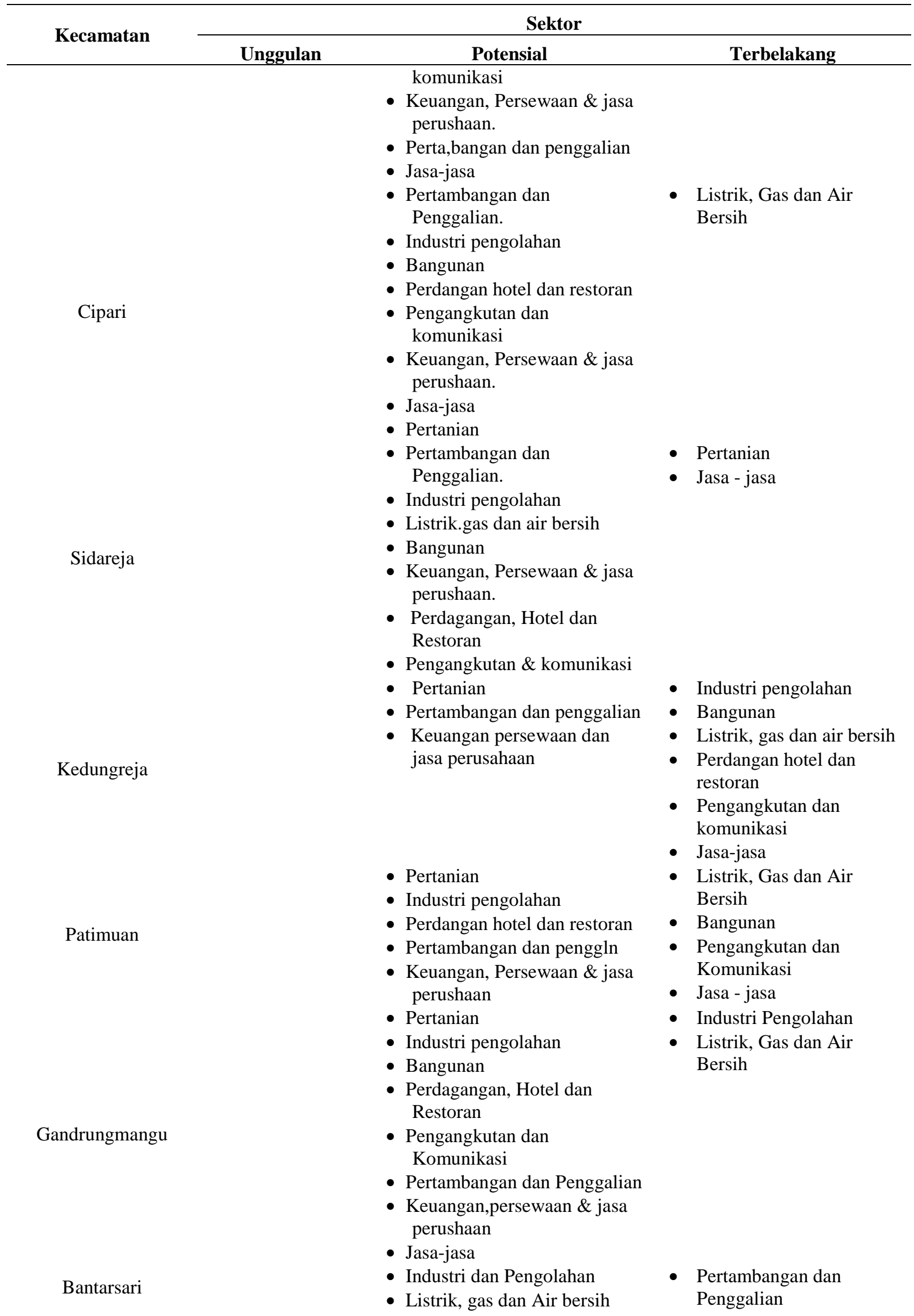




\begin{tabular}{|c|c|c|c|}
\hline \multirow{2}{*}{ Kecamatan } & \multicolumn{3}{|c|}{ Sektor } \\
\hline & Unggulan & Potensial & Terbelakang \\
\hline & & $\begin{array}{l}\text { - } \text { Bangunan } \\
\text { - Perdangan hotel dan restoran } \\
\text { - Pengangkutan dan } \\
\text { komunikasi } \\
\text { - Keuangan, Persewaan \& jasa } \\
\text { perushaan } \\
\text { - Pertanian }\end{array}$ & - Jasa - jasa \\
\hline Kawunganten & $\begin{array}{l}\text { - Pertanian } \\
\text { - Keuangan, } \\
\text { Persewaan \& } \\
\text { jasa perushaan }\end{array}$ & $\begin{array}{l}\text { - Pertambangan dan Penggalian } \\
\text { - Industri pengolahan } \\
\text { - Listrik, Gas dan Air Bersih } \\
\text { - Bangunan } \\
\text { - Perdagangan, Hotel dan } \\
\quad \text { Restoran } \\
\text { - Pengangkutan dan } \\
\quad \text { Komunikasi }\end{array}$ & - Jasa - jasa \\
\hline & - Pertanian & $\begin{array}{l}\text { - Industri pengolahan } \\
\text { - Listrik.gas dan air bersih } \\
\text { - Bangunan } \\
\text { - Perdangan hotel dan restoran }\end{array}$ & $\begin{array}{l}\text { - Pertambangan dan } \\
\text { Penggalian. }\end{array}$ \\
\hline Kampung Laut & & $\begin{array}{l}\text { - Pengangkutan dan } \\
\text { komunikasi } \\
\text { - Keuangan, Persewaan\&jasa } \\
\text { perush } \\
\text { - Jasa - jasa }\end{array}$ & \\
\hline Jeruklegi & & $\begin{array}{l}\text { - Industri Pengolahan } \\
\text { - Listrik, Gas dan Air Bersih } \\
\text { - Pengangkutan dan } \\
\text { komunikasi } \\
\text { - Pertambangan dan } \\
\text { Penggalian. }\end{array}$ & $\begin{array}{ll}\text { - } & \text { Pertanian } \\
\text { - } & \text { Bangunan } \\
\text { - } & \text { Perdagangan Hotel dan } \\
& \text { Restoran } \\
\text { - } & \text { Keuangan, Persewaan \& } \\
& \text { jasa perushaan } \\
\text { - Jasa - jasa }\end{array}$ \\
\hline Kesugihan & $\begin{array}{l}\text { - Pertambangan } \\
\text { dan } \\
\text { Penggalian }\end{array}$ & $\begin{array}{l}\text { - Pertanian } \\
\text { - Perdag, hotel \& restoran }\end{array}$ & $\begin{array}{ll}\text { - } & \text { Industri pengolahan } \\
\text { - } & \text { Listrik, Gas dan Air } \\
\text { Bersih } \\
\text { - } \text { Bangunan } \\
\text { - } \text { Pengangkutan dan } \\
\text { Komunikasi } \\
\text { - Keuangan, Persewaan \& } \\
\text { - jasa perushaan } \\
\text { - Jasa - jasa }\end{array}$ \\
\hline Adipala & & $\begin{array}{l}\text { - Pertambangan dan Penggalian } \\
\text { - Industri Pengolahan } \\
\text { - Listrik, gas dan Air Bersih. } \\
\text { - Perdangan hotel dan restoran } \\
\text { - Keuangan, Persewaan\&jasa } \\
\text { perush } \\
\text { - Jasa - jasa } \\
\text { - Pengangkutan dan } \\
\text { komunikasi }\end{array}$ & $\begin{array}{l}\text { - Pertanian } \\
\text { - Bangunan }\end{array}$ \\
\hline Maos & & $\begin{array}{l}\text { - Pertanian } \\
\text { - Pertambangan dan Penggalian } \\
\text { - Industri Pengolahan. } \\
\text { - Listrik, Gas dan Air Bersih }\end{array}$ & - Jasa - jasa \\
\hline
\end{tabular}




\begin{tabular}{|c|c|c|c|}
\hline \multirow{2}{*}{ Kecamatan } & \multicolumn{3}{|c|}{ Sektor } \\
\hline & Unggulan & Potensial & Terbelakang \\
\hline Sampang & $\begin{array}{l}- \text { Bangunan } \\
\text { - Keuangan, } \\
\text { Persewaan \& } \\
\text { jasa perushaan }\end{array}$ & $\begin{array}{l}\text { - Perdangan hotel dan restoran } \\
\text { - Pengangkutan dan } \\
\text { komunikasi } \\
\text { - Keuangan, Persewaan \& jasa } \\
\text { perusahaan } \\
\text { - Bangunan } \\
\text { - Industri pengolahan } \\
\text { - Listrik.gas dan air bersih } \\
\text { - Perdagangan, Hotel dan } \\
\text { - Restoran } \\
\text { - Jasa-jasa } \\
\text { - Pengangkutan \& komunikasi }\end{array}$ & $\begin{array}{l}\text { - } \text { Pertanian } \\
\text { - Pertambangan dan } \\
\text { Penggalian }\end{array}$ \\
\hline Kroya & $\begin{array}{l}\text { - Perdag, hotel } \\
\text { \& restoran }\end{array}$ & $\begin{array}{l}\text { - Pertanian } \\
\text { - Pertambangan dan Penggalian } \\
\text { - Listrik, Gas dan Air Bersih } \\
\text { - Industri Pengolahan } \\
\text { - Bangunan } \\
\text { - Pengangkutan dan } \\
\text { komunikasi } \\
\text { - Keuangan, Persewaan \& jasa } \\
\text { perusahaan }\end{array}$ & - Jasa - jasa \\
\hline Binangun & & $\begin{array}{l}\text { - Listrik, gas dan Air Bersih. } \\
\text { - Pengangkutan dan } \\
\text { Komunikasi } \\
\text { - Bangunan }\end{array}$ & $\begin{array}{ll}\text { - } & \text { Pertanian } \\
\text { - } & \text { Pertambangan dan } \\
& \text { Penggalian } \\
\text { - } & \text { Industri Pengolahan } \\
\text { - } & \text { Perdagangan, Hotel dan } \\
& \text { Restoran } \\
\text { - } & \text { Keuangan, Persewaan \& } \\
& \text { jasa perushaan } \\
\text { - } & \text { Jasa-jasa }\end{array}$ \\
\hline Nusawungu & & $\begin{array}{l}\text { - } \text { Pertanian } \\
\text { - Pertambangan danm } \\
\text { Penggalian } \\
\text { - Listrik, gas dan Air bersih } \\
\text { - } \text { Bangunan } \\
\text { - Keuangan, persewaan dan } \\
\text { jasa perusahaan }\end{array}$ & $\begin{array}{l}\text { - Industri Pengolahan } \\
\text { - Perdagangan, Hotel dan } \\
\text { Restoran } \\
\text { - Pengangkutan dan } \\
\text { Komunikasi } \\
\text { - Jasa-jasa }\end{array}$ \\
\hline Cilacap Selatan & $\begin{array}{l}\text { - Pertambangan } \\
\text { dan } \\
\text { Penggalian }\end{array}$ & $\begin{array}{l}\text { - Bangunan } \\
\text { - Perdangan hotel dan restoran } \\
\text { - Pengangkutan dan } \\
\text { komunikasi } \\
\text { - Jasa - jasa } \\
\text { - Industri pengolahan } \\
\text { - Listrik, gas\&air bersih }\end{array}$ & $\begin{array}{l}\text { - Keuangan, } \\
\text { Persewaan\&jasa perush } \\
\text { - Pertanian }\end{array}$ \\
\hline Cilacap Tengah & $\begin{array}{ll}\text { - } & \text { Industri } \\
& \text { pengolahan } \\
\text { - } & \text { Listrik, Gas } \\
& \text { dan Air Bersih } \\
\text { - } & \text { Bangunan } \\
\text { - Jasa - jasa }\end{array}$ & $\begin{array}{l}\text { - Perdangan hotel dan restoran } \\
\text { - Keuangan, Persewaan \& jasa } \\
\text { perushaan } \\
\text { - Pengangkutan \& komunikasi }\end{array}$ & $\begin{array}{l}\text { - Pertanian } \\
\text { - Pertambangan dan } \\
\text { Penggalian. }\end{array}$ \\
\hline Cilacap Utara & $\begin{array}{l}\text { - Listrik, gas \& } \\
\text { air bersih } \\
\text { - } \text { Industri } \\
\end{array}$ & $\begin{array}{l}\text { - Keuangan, Persewaan \& jasa } \\
\text { perushaan }\end{array}$ & $\begin{array}{ll}\text { - } & \text { Pertanian } \\
\text { - } & \text { Pertambangan dan } \\
& \text { Penggalian } \\
\end{array}$ \\
\hline
\end{tabular}




\begin{tabular}{llll}
\hline \multirow{2}{*}{ Kecamatan } & \multicolumn{2}{c}{ Sektor } \\
\cline { 2 - 4 } & Unggulan & Potensial & \multicolumn{1}{c}{ Terbelakang } \\
\hline & Pengolahan & $\bullet$ Perdag, hotel \& restoran \\
& $\bullet$ Bangunan & $\bullet$ Pengangkutan dan \\
& $\bullet$ Jasa-jasa & Komunikasi \\
\hline
\end{tabular}

